\title{
(2) OPEN ACCESS \\ Cheiro-oral syndrome secondary to thalamic infarction: a clinical syndrome a physician should know
}

\author{
Chiew Sern Ong 지 , Jiaqing Xiong, You Jiang Tan
}

Neurology, Singapore General Hospital, Singapore

\section{Correspondence to Dr Chiew Sern Ong; ong.chiew.sern@singhealth. com.sg}

Accepted 24 September 2020

\section{DESCRIPTION}

A 79-year-old Indian man presented acutely to our centre with numbness over his left perioral region and the fingertips on his left hand. These symptoms began simultaneously earlier in the day. $\mathrm{He}$ has significant vascular risk factors of ischaemic heart disease, hypertension, hyperlipidaemia and diabetes mellitus. Examination revealed sensory deficits to pain and discriminative touch over his left perioral region and the fingertips of his left second to fifth digits. There were no motor or cranial nerve deficits. Brain MRI showed an acute infarct involving the right thalamus (figure 1A,B). Magnetic resonance angiography showed diffuse atherosclerosis of the intracranial vessels. The mechanism of the ischaemic stroke was attributed to small vessel disease. He was started on antiplatelet therapy, and the control of his vascular risk factors was improved. His symptoms have completely resolved when reviewed a month after discharge.

Cheiro-oral syndrome is a rare variant of thalamic stroke syndromes, with sensory impairment involving the fingers and the perioral regions. It is poorly recognised, and is easily missed and discounted due to the atypicality in the geographical extent of the clinical symptoms and signs. It was first described by Sittig, who described the cortical localisation of the offending lesion. ${ }^{1}$ Thalamic lesions were subsequently reported later by other authors. ${ }^{2}$ Satpute's group further classified the syndrome into four types based on the distribution of sensory deficits (table 1), of which type I best describes our patient's clinical symptoms and signs. ${ }^{3}$

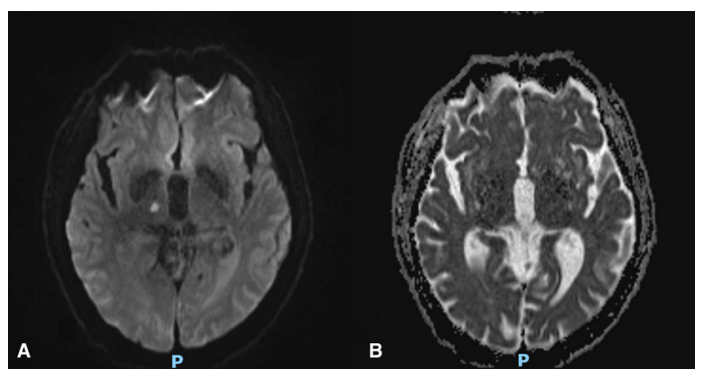

Figure 1 (A) DWI sequence of MRI brain showing acute infarction of the right thalamus. (B) ADC sequence of MRI brain showing acute infarction of the right thalamus. $D W I$, diffusion weighted imaging; $A D C$, apparent diffusion coefficient.

\begin{tabular}{ll}
\hline Table 1 & Types of cheiro-oral syndrome \\
\hline $\begin{array}{l}\text { Types of cheiro-oral } \\
\text { syndrome }\end{array}$ & Clinical manifestations \\
\hline Type I & $\begin{array}{l}\text { Perioral area and unilateral finger(s)/hand } \\
\text { Type II }\end{array}$ \\
Type III & $\begin{array}{l}\text { Perioral area and bilateral finger(s)/hand } \\
\text { one is involved bilaterally whereas } \\
\text { another one is unilateral }\end{array}$ \\
Type IV & Perioral area and opposite finger(s)/hand \\
\hline
\end{tabular}

Learning points

Cheiro-oral syndrome, though rare, has significant localising value.

- Cheiro-oral syndrome can be caused by ischaemic strokes, and should not be missed.

The thalamus is a vital relay centre in the brain. Nearly all pathways projecting to the cortex pass through the thalamus. With a total of seven relay nuclei, the ventral posterior medial (VPM) and the ventral posterior lateral (VPL) thalamic nuclei are especially relevant in the pathogenesis of cheirooral syndrome. The VPM receives sensory input from the trigeminal nerve, whereas the VPL nuclei receives sensory input from the upper limbs. Due to their proximity, structural lesions such as an infarct can result in the pattern of sensory deficits characteristic of the syndrome, as demonstrated by our patient. ${ }^{4}$

The clinical significance of cheiro-oral syndrome cannot be understated. Prompt recognition allows for early identification and treatment of ischaemic strokes. Conversely, failure to do so has detrimental implications, resulting in delaying targeted stroke treatment, and places the patient at increased risk of stroke recurrences and its inherent morbidity and mortality. Through the case described herein, we therefore seek to highlight the importance of recognising this uncommon stroke syndrome, so that timely treatment may be administered.

Contributors CSO is responsible for the construct of the manuscript as a whole including data analysis and research. JX helped in describing the case presented and obtaining consent. YJT helped in editing of manuscript. All three of us are involved in the patient's care. 
Images in...

Funding The authors have not declared a specific grant for this research from any funding agency in the public, commercial or not-for-profit sectors.

Competing interests None declared.

Patient consent for publication Obtained.

Provenance and peer review Not commissioned; externally peer reviewed.

Open access This is an open access article distributed in accordance with the Creative Commons Attribution Non Commercial (CC BY-NC 4.0) license, which permits others to distribute, remix, adapt, build upon this work non-commercially, and license their derivative works on different terms, provided the original work is properly cited and the use is non-commercial. See: http://creativecommons.org/ licenses/by-nc/4.0/.
ORCID iD

Chiew Sern Ong http://orcid.org/0000-0002-5718-4176

\section{REFERENCES}

1 Sittig O. Klinische Beitrage Zur Lehre von der Lokalisation Der sensiblen Rindenzentren. Prager Med Wochenschr 1914;45:548-50.

2 Bogousslavsky J, Regli F, Uske A. Thalamic infarcts: clinical syndromes, etiology, and prognosis. Neurology 1988:38:837-48.

3 Satpute S, Bergquist J, Cole JW. Cheiro-Oral syndrome secondary to thalamic infarction: a case report and literature review. Neurologist 2013;19:22-5.

4 Garcin R, Lapresle J. [2d personal observation of a sensory syndrome of the thalamic type with cheiro-oral topography caused by localized lesion of the thalamus]. Rev Neurol 1960;103:474-81.

Copyright 2020 BMJ Publishing Group. All rights reserved. For permission to reuse any of this content visit

https://www.bmj.com/company/products-services/rights-and-licensing/permissions/

BMJ Case Report Fellows may re-use this article for personal use and teaching without any further permission.

Become a Fellow of BMJ Case Reports today and you can:

- Submit as many cases as you like

- Enjoy fast sympathetic peer review and rapid publication of accepted articles

Access all the published articles

Re-use any of the published material for personal use and teaching without further permission

Customer Service

If you have any further queries about your subscription, please contact our customer services team on +44 (0) 2071111105 or via email at support@bmj.com.

Visit casereports.bmj.com for more articles like this and to become a Fellow 